\title{
Bacterial (9A2H) enhancement alters the nematode community structure and decomposition pathway of amended nutrient-limited soil
}

\author{
DEMA R. LUCKYANA, I G. A. AYU RATNA PUSPITASARI, ARDHINI R. MAHARNING \\ Faculty of Biology, Universitas Jenderal Soedirman, Jl. dr. Suparno 63, Purwokerto Utara, Banyumas 53122, Central Java, Indonesia, \\ Tel./fax.: +62-281-625865, `email: ardhini.maharning @unsoed.ac.id
}

Manuscript received: 4 July 2020. Revision accepted: 25 September 2020.

\begin{abstract}
Luckyana DR, Puspitasari IGAAR, Maharning AR. 2020. Bacterial (9A2H) enhancement alters the nematode community structure and decomposition pathway of amended nutrient-limited soil. Biodiversitas 21: 4813-4820. This study examined the influence of paddy litter amendment and bacterial enhancement of nutrient-limited soil on the nematode community structure and investigated the decomposition rate of the litter due to the treatment. We applied a microcosm-based approach using sand as the medium, including the following treatments: no-bacteria, 9A-autotrophic-bacteria, 2H-heterotrophic-bacteria, and 9A-2H-mix-bacteria, with five replicates. The litter bag experiment and exponential decay model estimated the litter decomposition rate in the microcosm. The soil samples and litter bags were retrieved after days 21, 42, and 63. The structure, enrichment, channel index (CI), and canonical correspondence analysis were employed to investigate the nematode community response. Bacterial enhancement shifted the nematode community and the soil food web toward the dominant bacterial pathway by day 63 (CI: 0), with a slightly less structured food web that was supported by bacterivorous nematodes mostly related to available nutrients. These changes coincided with soil organic carbon and nitrogen increases over time. Our experiments showed that paddy litter amendment and the 9A, 2H, and 9A-2H-mix bacterial enhancements improved nutrient-limited soil, according to the analysis of the nematode community, its composition, and the food web conditions determining nutrient mobility and availability. However, these factors have no impact on the litter decay rate.
\end{abstract}

Keywords: Baerman funnel method, forest soil resource, nematode feeding group, paddy litter decomposition, soil food web index

\section{INTRODUCTION}

Nematodes are the most abundant and dominant metazoans in soil and interact with one another through a food web (Van Den Hoogen et al. 2019; Wilschut et al. 2019). The trophic structure links omnivorous, carnivorous, bacterivorous, and fungivorous nematodes within the soil microfood web responsible for decomposing organic matter and nutrient cycling. In the web, bacteria and fungi are the primary decomposers that enzymatically degrade complex organic substances and function as nutrient sources for nematodes. These primary decomposers regulate the bacterivorous and fungivorous nematode populations, most likely by means of bottom-up control (Ferris 2010; Scharroba et al. 2016; Zhang et al. 2016). The close linkages between these trophic levels give rise to the fundamental concept that changes in nutrient sources, such as bacterial abundance and composition, might lead to changes in the higher trophic levels of the soil food web, such as the nematode community.

Microfood web development is partly determined by available organic matter, as the basal resource in the soil environment (Morriien 2016; Sauvadet et al. 2016). Organic matter is the carbon source used by soil bacteria and fungi. Bacteria use labile substances, and fungi utilize both labile and recalcitrant substances in organic matter. They promote the growth of bacterivorous or fungivorous nematodes via changes in bacterial and fungal communities, therefore altering the nematode composition, which might progress toward the bacterial or fungal decomposition pathway. The classical food web view indicates that soil organic matter containing labile substances is related to bacterial energy channels and that resistant substances in organic matter stimulate fungal energy channels (De Vries and Caruso 2016).

The linkages between trophic levels in the soil food web, the control exerted by microorganisms on their feeder populations, and the influence of soil organic matter on the nematode community suggest a food web concept that is applicable for improving nutrient-limited soil. The food web system is expected to mobilize nutrients through trophic linkages, to mineralize soil organic matter by feeding and enzymatic activities, and to improve soil structure by forming soil aggregates, thereby creating heterogeneity and a suitable microclimate for soil organisms (Kardol et al. 2016). Trophic linkage complexity might indicate functional improvement of nutrient-limited soil because the soil food web is most likely to include more trophic linkages as the habitat progresses toward the natural stage (Hannula et al. 2017).

As nutrient resources for soil nematodes, bacteria have the potential to be enhancing agents supporting and determining nematode community development in nutrientlimited soil, leading to the further mobilization of nutrients via the web and promotion of organic matter mineralization (Sauvadet et al. 2016). The bacteria require soil organic matter as their growth medium and nutrient sources to play their role during the enhancement process in less fertile 
soil. Bacteria are capable of utilizing organic matter with labile carbon content. However, providing organic matter with a high content of labile carbon might promote quick nutrient release due to its high decomposability. Thus, there is a rapid decrease in the soil organic matter content in nutrient-limited soil. Organic matter with a high carbon content might provide sustainable nutrient sources because of the slow release of nutrients. Soil nematodes, as the dominant component of a microfood web, might respond accordingly. Changes in the nematode community driven by changes in food resources toward a highly functional community are expected to occur when an effort is made to improve soil fertility. Therefore, this concept is potentially applicable to nutrient-limited soil, as this soil is generally limited by soil organisms and soil organic matter (Fanin et al. 2019). Based on these concepts, we designed this research to (i) examine the effects of paddy litter amendment and bacterial enhancement on the nematode community structure of forest soil in nutrient-limited soil and (ii) investigate the decomposition rate of litter as a result of bacterial enhancement. It is expected that these experiments will provide an assessment of the method for improving soil quality.

\section{MATERIALS AND METHODS}

\section{Experimental design}

The experiments used a microcosm-based approach to collect independent soil samples from each experimental unit over time. Microcosms were prepared by placing sand to represent nutrient-limited soil and habitat for the soil organisms in incubation boxes $(60 \times 40 \times 20 \mathrm{~cm})$. The sand was randomly taken from River Serayu, spread evenly to a thin layer and sun-dried for three weeks before use to ensure that no biota inhabited the media. Each of the boxes was amended with a mixture of organic matter applied evenly to the surface and then homogenized with the top five $\mathrm{cm}$ of soil depth to provide extra resources and create a heterogeneous microhabitat for the soil organisms. Forest soil was added to the box as the source of soil biota. We applied four enhancement treatments with five replicates to the amended soil in the incubation boxes, i.e., no-bacterial enhancement as the control (NB), 9A-autotrophic bacteria (9A), 2H-heterotrophic bacteria $(2 \mathrm{H})$, and combined $9 \mathrm{~A}-2 \mathrm{H}$ (AH) (hereafter called the microcosm). The microcosms were placed in the greenhouse and maintained by daily watering.

\section{Preparation of organic matter mixture and resource soil}

The mixture consisted of paddy litter (leaves and straws) and a sugar solution prepared as follows. In a bucket, the precut paddy litter $(3-5 \mathrm{~cm})$ was regularly sprayed to maintain the appropriate moisture. In a separate box, the forest soil $(2,000 \mathrm{~g})$ was added to $100 \mathrm{~mL}$ sugar solution $\left(0.1\right.$ g. $\left.\mathrm{mL}^{-1}\right)$. Both were incubated for 2 weeks before amendment to the microcosm. For each microcosm, $200 \mathrm{~g}$ of paddy litter and $100 \mathrm{~g}$ of resource soil were added, followed by an additional sugar solution $(100 \mathrm{~mL})$. The forest soil (10-20 cm depth) was introduced from Mount Slamet forest $\left(572 \mathrm{~m}\right.$ above sea level, $7^{\circ} 19^{\prime} 33.0^{\prime \prime} \mathrm{S}$ $\left.109^{\circ} 13^{\prime} 03.0 " \mathrm{E}\right)$, dominated by Agathis dammara.

\section{Bacterial enhancement}

Two types of bacteria were added to the microcosm to enhance the soil community. Their selection was based on our previous research to which the bacteria have consistently thrived in the soil planted with various vegetation and during drought treatments (Maharning et al. 2016). Their survival has potential for enhancement agents. The $2 \mathrm{H}$ bacteria belong to the genus Bacillus (isolate $2 \mathrm{H}$ ), the 9A bacteria (isolate 9A) yet unidentified but characterized by their colony color of clear or purple, irregular shape, undulate margin, raised elevation, and coccoid bacterial cells $(0.25 \times 0.125-0.25 \mu \mathrm{m})$. Before use, both bacterial isolates were recultured in nutrient broth medium and incubated for 48 hours at $37^{\circ} \mathrm{C}$. For the enhancement treatments, the bacterial culture was poured onto the microcosm after dilution to $100 \mathrm{~mL}$ to provide even spreading. Each microcosm was enhanced with $10^{10}$ bacterial cells, which represented their typical abundance in our previous study (Maharning et al. 2016, unpublished).

\section{Litter-bag experiments}

These experiments measured the short-term decomposition rate of paddy litter for 63 days. It was prepared by placing $2 \mathrm{~g}$ of paddy litter into a litter bag (1$\mathrm{mm}$ mesh size). There were 60 litter bags buried inside the microcosm ( 3 bags in each microcosm). The bags were retrieved according to soil sampling to follow the decomposition rate. The recovered litter was oven-dried for 48 hours at $105^{\circ} \mathrm{C}$ and then scaled to obtain its dry weight. The dry litter was measured for its ash weight by placing it in a muffle furnace $\left(4\right.$ hours at $\left.500^{\circ} \mathrm{C}\right)$. The decomposition rate was calculated following the decay rate model, $\mathrm{X}_{\mathrm{t}} / \mathrm{X}_{0}=$ $\mathrm{e}^{-\mathrm{kt}}$, where $\mathrm{X}_{t} / \mathrm{X}_{0}$ is the proportion of original mass remaining at time $\mathrm{t}$, and $\mathrm{k}$ is the decomposition rate constant (Beyaert and Fox 2008). The model assumes $100 \%$ ash-free dry mass at day 0 , before treatment.

\section{Soil sampling}

Soil samples (100 g) were taken from the microcosm on days 21,42 , and 63 to observe temporal changes. The samples were measured for nematode enumeration and physicochemical properties, including soil organic carbon and total soil nitrogen. Soil $\mathrm{pH}$, moisture, and temperature measurements were taken from the microcosms at the time of sampling. The forest soil used as the source of soil biota was recorded to represent week zero for nematode abundance. The preliminary observation revealed no nematodes in the sand media. The litter bags were also retrieved following soil sampling (20 bags per sampling). During the entire experiment, the nematode data covered 60 sampling units (4 treatments $\mathrm{x} 5$ replicates $\mathrm{x} 3$ sampling days). The soil organic carbon (spectrophotometry) and total soil nitrogen (Kjeldahl method) were estimated at day 21 and day 63 to observe their changes after 42 days (40 units $=4$ treatments $\times 5$ replicates $\times 2$ sampling days).

\section{Nematode extraction}

We applied the Baermann funnel method to extract the nematodes (Forge and Kimpinski 2008). Samples included forest soil and microcosm soil. The preweighed soil sample $(15 \mathrm{~g})$ was wrapped in a piece of tissue paper and submerged in a distilled-water-filled funnel. After 48 
hours, the nematodes were collected by releasing the hoseattached clamp to the funnel. Five to seven milliliters of the solution were transferred into the conical tube, and the nematodes were fixed in $4 \%$ formaldehyde final solution. The nematode abundance was then converted into the number of individuals in $10 \mathrm{~g}$ soil. Nematode enumeration was observed under an inverted microscope. Their identification followed Bongers (1994) to their family level of a taxon, which is required to classify them into their c-p values and weight values for the food web profile (Bongers 1999; Ferris et al. 2001). They were also classified into their feeding group following Forge and Tenuta (2008).

\section{Data analysis}

We employed a two-way analysis of variance to examine the significant difference in nematode abundance among the treatments (SigmaPlot 13). The nematode composition influenced by bacterial enhancement was investigated by ordination analysis, the canonical correspondence analysis (CCA) (Canoco 4.5). The analysis allows separation of different nematode compositions that the bacterial enhancement may affect. The food web indices were applied to measure the food web condition. They included the structure index (SI), enrichment index (EI), and channel index (CI) to indicate food web complexity, nutrient resource availability, and decomposition pathway, respectively (Ferris et al. 2001; Forge and Tenuta 2008). The formulas are as follows: SI = $(\mathrm{s} /(\mathrm{b}+\mathrm{s})) \times 100 ; \mathrm{EI}=(\mathrm{e} /(\mathrm{b}+\mathrm{e})) \times 100 ; \mathrm{CI}=(\mathrm{fe} / \mathrm{e}) \times 100$ where $s$ is the weighted abundance of structural taxa, $b$ is the weighted abundance of basal taxa, e is the weighted abundance of enrichment opportunists, and fe is the weighted abundance of fungivore enrichment opportunists.

\section{RESULTS AND DISCUSSION}

\section{Physico-chemical properties of the microcosm soil and litter decomposition rate}

Time was a significant factor affecting the physicochemical properties of the microcosm soil. The temperature $\left(30-33^{\circ} \mathrm{C}\right)$, moisture $(26-65 \%)$, water content (21-29\%), and $\mathrm{pH}(6.96-7.08)$ of the microcosm soil were similar across the treatments. Overall, organic carbon and total nitrogen showed an increase over 41 days (from day 21 to day 63) but varied among bacterial enhancement treatments. The highest increases were observed in organic carbon $(46.64 \%)$ and total nitrogen $(43.67 \%)$ under the 9A enhancement (Table 1). This pattern was consistent with the biplot showing that total nitrogen $(\mathrm{N})$ and organic carbon (C) increased with time (Figure 1).

The litter decay rate declined with time, which was consistent with the increase in the remaining mass (Figure 1). This suggests slower litter decay at later stages of decomposition than at early stages. The paddy litter decomposition rate showed no difference $(p=0.292)$ among the bacterial enhancements. The decay rate model revealed that paddy litter mass was lost at a rate of $0.029 \%$ day $^{-1}$ under the NB treatment and $0.019 \%$. day ${ }^{-1}$ under 9A enhancement. For the other two treatments, the rates were $0.016 \%$ day $^{-1}$ and $0.026 \%$ day $^{-1}$ under $2 \mathrm{H}$-and $\mathrm{AH}$ enhancement, respectively (Table 1).

\section{Nematode diversity}

Overall, there were 18 families of free-living nematodes representing four feeding groups and one family of fungivore-root-hair feeders (Tylenchidae) observed from the microcosm soil (Table 2). Two families appeared only after day 21, Anguinidae (fungivore) and Diplogasteridae (bacterivore), and the other two, Cyatolaimidae and Panagrolaimidae, were present in a later stage (day 42). The family richness varied following the enhancement across time, with day 42 showing the highest richness (6-11 families) and the most diverse feeding groups (5 feeding groups). Declining family richness began to be observed at day 63 (4-10 families, 3 feeding groups). The 9A enhancement accommodated greater family richness and more feeding groups compared to the other bacterial enhancements.

Table 1. Soil organic carbon and total nitrogen contents and their changes from day 21 to day 63 (41 days) in the microcosms, followed by the rate of paddy litter decay according to bacterial enhancement.

\begin{tabular}{lcccc}
\hline \multicolumn{1}{c}{ Parameter } & \multicolumn{3}{c}{ Bacterial Enhancement Treatment } \\
\cline { 2 - 5 } & NB & $\mathbf{9 A}$ & $\mathbf{2 H}$ & $\mathbf{A H}$ \\
\hline Soil organic carbon (\%) & & & & \\
Day-21 & $0.268 \pm 0.076$ & $0.239 \pm 0.045$ & $0.206 \pm 0.052$ & $0.252 \pm 0.078$ \\
Day-63 & $0.309 \pm 0.047$ & $0.350 \pm 0.055$ & $0.297 \pm 0.063$ & $0.252 \pm 0.064$ \\
Difference of C content & +0.041 & +0.111 & 0.00 \\
Percent difference of C content & 15.29 & 46.64 & +0.091 & 0.00 \\
Soil total Nitrogen (\%) & & & \\
Day-21 & $0.039 \pm 0.003$ & $0.032 \pm 0.006$ & $0.042 \pm 0.006$ & $0.039 \pm 0.012$ \\
Day-63 & $0.048 \pm 0.008$ & $0.045 \pm 0.006$ & $0.037 \pm 0.007$ & $0.039 \pm 0.007$ \\
Difference of N content & +0.009 & +0.013 & -0.005 & 0,00 \\
Percent difference of N content & 21.54 & 43.67 & -11.00 & 0.00 \\
Decomposition rate (\%.day ${ }^{-1}$ ) & 0.029 & 0.019 & 0.016 & 0.026 \\
\hline
\end{tabular}

Note: NB: No-Bacteria, 9A: 9A-Autotrophic-Bacteria, 2H: 2H-Heterotrophic-Bacteria, AH: 9A-2H-Mix-Bacteria. Organic carbon of sand: $0.412 \%$, forest soil: $6.858 \%$. Total nitrogen of sand: $0.037 \%$, forest soil: $0.611 \%$. (mean \pm SE), $(+)$ positive and (-) negative values indicate increasing and decreasing substances, respectively 
Table 2. Nematode families inhabiting microcosm soil enhanced with bacteria, their feeding groups, c-p scaling, and abundance over 63 days of incubation.

\begin{tabular}{|c|c|c|c|c|c|c|}
\hline \multirow{2}{*}{ Family } & \multirow{2}{*}{ Feeding group } & \multirow{2}{*}{$\begin{array}{c}\text { c-p } \\
\text { scaling }\end{array}$} & \multicolumn{4}{|c|}{ Nematode abundance (individual.10 ${ }^{-1}$ g soil) } \\
\hline & & & NB & $\mathbf{9 A}$ & $2 \mathbf{H}$ & $\mathbf{A H}$ \\
\hline \multicolumn{7}{|l|}{ Day-0 (Forest Soil) } \\
\hline Alamidae & $\mathrm{B}$ & 4 & & & & \\
\hline Aphelenchidae & $\mathrm{F}$ & 2 & & & & \\
\hline Aphelenchoididae & $\mathrm{F}$ & 2 & & & & \\
\hline Cephalobidae & $\mathrm{B}$ & 2 & & & & \\
\hline Rhabditidae & $\mathrm{B}$ & 1 & & & & \\
\hline Prismatolaimidae & $\mathrm{B}$ & 3 & & & & \\
\hline \multirow[t]{3}{*}{ Qudsianematidae } & $\mathrm{O}$ & 4 & & & & \\
\hline & & Total & & & & \\
\hline & \multicolumn{2}{|c|}{ Family richness } & & & & \\
\hline \multicolumn{7}{|l|}{ Day-21 } \\
\hline Anguinidae & $\mathrm{F}$ & 2 & 0 & 0 & 0 & 1 \\
\hline Cephalobidae & $\mathrm{B}$ & 2 & 3 & 9 & 2 & 2 \\
\hline Diplogasteridae & $\mathrm{B}$ & 1 & 1 & 0 & 0 & 0 \\
\hline Monhysteridae & $\mathrm{B}$ & 2 & 0 & 1 & 1 & 0 \\
\hline Plectidae & $\mathrm{B}$ & 2 & 1 & 13 & 3 & 4 \\
\hline Prismatolaimidae & $\mathrm{B}$ & 3 & 0 & 1 & 0 & 1 \\
\hline Rhabditidae & $\mathrm{B}$ & 1 & 3 & 11 & 10 & 4 \\
\hline Qudsianematidae & $\mathrm{O}$ & 4 & 0 & 1 & 6 & 0 \\
\hline Teratocephalidae & $\mathrm{B}$ & 3 & 0 & 0 & 1 & 0 \\
\hline Tripylidae & B & 3 & 0 & 1 & 0 & 0 \\
\hline \multirow{3}{*}{ Tylenchidae } & $\mathrm{F}-\mathrm{Rh}$ & 3 & 3 & 0 & 0 & 0 \\
\hline & \multirow{2}{*}{\multicolumn{2}{|c|}{$\begin{array}{l}\text { Total } \\
\text { Family richness }\end{array}$}} & 11 & 37 & 23 & 12 \\
\hline & & & 5 & 7 & 7 & 5 \\
\hline \multicolumn{7}{|l|}{ Day-42 } \\
\hline Alamidae & B & 4 & 1 & 0 & 0 & 1 \\
\hline Aphelenchidae & $\mathrm{F}$ & 2 & 1 & 0 & 0 & 0 \\
\hline Aphelenchoididae & $\mathrm{F}$ & 2 & 1 & 0 & 0 & 0 \\
\hline Cephalobidae & $\mathrm{B}$ & 2 & 0 & 7 & 7 & 1 \\
\hline Cyatolaimidae & $\mathrm{O}$ & 3 & 2 & 1 & 0 & 0 \\
\hline Monhysteridae & $\mathrm{B}$ & 2 & 0 & 1 & 0 & 0 \\
\hline Mononchidae & $\mathrm{C}$ & 4 & 2 & 1 & 0 & 0 \\
\hline Panagrolaimidae & $\mathrm{B}$ & 1 & 0 & 0 & 1 & 1 \\
\hline Plectidae & $\mathrm{B}$ & 2 & 3 & 26 & 11 & 7 \\
\hline Prismatolaimidae & $\mathrm{B}$ & 3 & 0 & 1 & 0 & 0 \\
\hline Qudsianematidae & $\mathrm{O}$ & 4 & 15 & 3 & 12 & 4 \\
\hline Rhabditidae & $\mathrm{B}$ & 1 & 0 & 22 & 23 & 14 \\
\hline Rhabdolaimidae & $\mathrm{B}$ & 3 & 0 & 1 & 1 & 0 \\
\hline Teratocephalidae & $\mathrm{B}$ & 3 & 0 & 2 & 0 & 0 \\
\hline Thornenematidae & $\mathrm{O}$ & 5 & 4 & 0 & 0 & 0 \\
\hline Tripylidae & B & 3 & 1 & 11 & 0 & 0 \\
\hline \multirow[t]{3}{*}{ Tylenchidae } & $\mathrm{F}-\mathrm{Rh}$ & 3 & 0 & 0 & 2 & 0 \\
\hline & \multirow{2}{*}{\multicolumn{2}{|c|}{$\begin{array}{l}\text { Total } \\
\text { Family richness }\end{array}$}} & 30 & 76 & 57 & 28 \\
\hline & & & 9 & 11 & 7 & 6 \\
\hline \multicolumn{7}{|l|}{ Day-63 } \\
\hline Alamidae & $\mathrm{B}$ & 4 & 1 & 2 & 0 & 2 \\
\hline Cephalobidae & $\mathrm{B}$ & 2 & 0 & 25 & 24 & 10 \\
\hline Mononchidae & $\mathrm{C}$ & 4 & 3 & 0 & 0 & 0 \\
\hline Plectidae & $\mathrm{B}$ & 2 & 10 & 43 & 26 & 21 \\
\hline Prismatolaimidae & $\mathrm{B}$ & 3 & 0 & 6 & 0 & 0 \\
\hline Rhabditidae & $\mathrm{B}$ & 1 & 0 & 29 & 38 & 25 \\
\hline Rhabdolaimidae & $\mathrm{B}$ & 3 & 0 & 3 & 0 & 0 \\
\hline Qudsianematidae & $\mathrm{O}$ & 4 & 34 & 23 & 28 & 14 \\
\hline Teratocephalidae & $\mathrm{B}$ & 3 & 0 & 1 & 0 & 0 \\
\hline Thornenematidae & $\mathrm{O}$ & 5 & 0 & 4 & 0 & 0 \\
\hline \multirow[t]{3}{*}{ Tripylidae } & $\mathrm{B}$ & 3 & 1 & 8 & 0 & 0 \\
\hline & \multirow{2}{*}{\multicolumn{2}{|c|}{$\begin{array}{r}\text { Total } \\
\text { Family Richness }\end{array}$}} & 49 & 144 & 116 & 72 \\
\hline & & & 5 & 10 & 4 & 5 \\
\hline
\end{tabular}

Note: NB: no-bacterial enhancement, 9A: 9A-autotrophic bacterial enhancement, 2H: 2H-heterotrophic bacterial enhancement, AH: 9A2H-mix enhancement, B: Bacterivore, F: Fungivore, O: Omnivore, C: Carnivore, F-Rh: Fungivore-root-hair feeder 
Although nematode abundance decreased at day 21, overall nematode abundance showed an increasing pattern over time (Table 2 and Figure 1), and a significant difference in nematode numbers was observed due to bacterial enhancement $(p=0.018)$ over time $(p=0.002)$. The highest abundance occurred at day 63 for all bacterial enhancement (4.9-14.4 individuals. $\left.{ }^{-1}\right)$. On day 21, the community in all treatments showed lower abundance (1.13.7 individuals. $\left.\mathrm{g}^{-1}\right)$ than forest soil (7.9 individuals. $\left.\mathrm{g}^{-1}\right)$ used as the resource during the experiments. Some families (i.e., Alamidae, Aphelenchidae, and Aphelenchoididae) were absent from the microcosms, and others (Cephalobidae and Prismatolaimidae) decreased. After 63 days, the nematode abundance increased in the $9 \mathrm{~A}$ and $2 \mathrm{H}$ treatments but not in the others, and the 9A enhancement showed the largest abundance (14.4 individuals. ${ }^{-1}$ ). Compared to day 0 (represented by nematodes of the forest-soil community), the increase reached $82.28 \%$ for $9 \mathrm{~A}$ and $46.83 \%$ for $2 \mathrm{H}$. The abundance of $\mathrm{NB}$ and $\mathrm{AH}$ enhancement decreased to $37.97 \%(\mathrm{NB})$ and $8.86 \%(\mathrm{AH})$. However, when the proportion of increase (from day 21 to day 63) across bacterial enhancement was calculated, it revealed a range of 74.31-83.33\% (addition of $\pm 2 \%$. day $^{-1}$ or 1-2 individuals.day $\left.{ }^{-1}\right)$, indicating a similar rate of increase in nematode abundance for all treatments ( $p=$ 0.699).

The identification of nematodes to the feeding group level is necessary to analyze their community profile and to reveal the soil food web condition. Bacterivores were persistent under all enhancement treatments, although their numbers were varied. Omnivores were prominent by the end of the experiments under all bacterial enhancement treatments. For NB soil, carnivores were present (Figure 1).

The nematode community served as an indicator of the decomposition pathway and a food web profile based on their family taxon level and feeding group. The decomposer food web of the microcosm soil with bacterial enhancement was shown to dominate early by the bacterial pathway, as demonstrated by low values of the channel index (CI) at day 21. The CIs for 9A-, 2H-, and $\mathrm{AH}$ enhancements were between 0 and 5.9 during the experiments. For NB, the CI was 20 on day 21 and then escalated to 100 , indicating complete fungal control during decomposition. However, it declined to 0 by the end of the experiment, suggesting it was taken over by bacterial control during decomposition (Table 3).

Table 3. Channel index indicating the fungal decomposition pathway of the soil food web in the microcosm soil.

\begin{tabular}{lcccc}
\hline \multirow{2}{*}{ Time } & \multicolumn{4}{c}{ Channel Index (CI) } \\
\cline { 2 - 5 } & NB & $\mathbf{9 A}$ & $\mathbf{2 H}$ & $\mathbf{A H}$ \\
\hline Day-0 & 28.6 & 28.6 & 28.6 & 28.6 \\
Day-21 & 20.0 & 0.0 & 00.0 & 5.9 \\
Day-42 & 100.0 & 0.0 & 1.00 & 0.0 \\
Day-63 & 0.0 & 0.0 & 0.0 & 0.0 \\
\hline
\end{tabular}

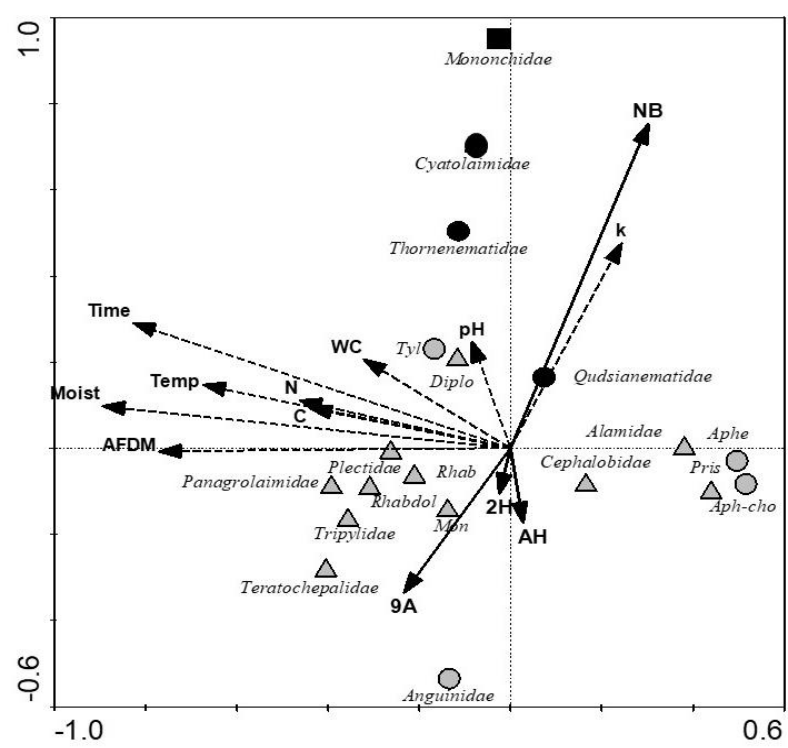

Figure 1. CCA biplot relating environmental factors and nematode family dynamics affected by bacterial enhancement over time. The eigenvalue of Axis-1: 0.422, Axis-2: 0.132 with cumulative percent variance of family-environment relation reached 52.4 (Axis-1) and 68.8 (Axis-2), family-environment correlations were 0.93 and 0.71 for Axis-1 and Axis-2, respectively, $p_{\text {axis }-1}=0.016, p_{\text {all-axes }}=0.018$ [environmental factors included soil temperature (Temp), moisture (Moist), water content (WC), remaining mass (AFDM), decay rate $(\mathrm{k}), \mathrm{pH}$, organic carbon $(\mathrm{C})$, total nitrogen $(\mathrm{N})$, time, no-bacterial enhancement (NB), 9A-autotrophic bacterial enhancement (9A), 2Hheterotrophic bacterial enhancement $(2 \mathrm{H}), 9 \mathrm{H}-2 \mathrm{H}-m i x$ bacterial enhancement $(\mathrm{AH})$ ] [nematode families included bacterivores: gray-circle, fungivores: grey upward triangle, omnivores: black circle, and carnivores: black square].

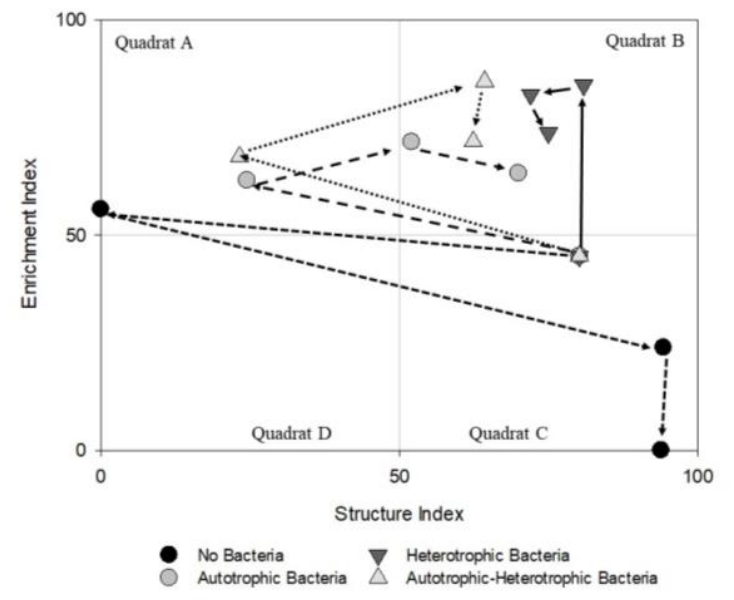

Figure 2. Nematode profile based on bacterial enhancement over time. The nematode community developed toward quadrats $\mathrm{A}$ or $\mathrm{B}$ before ending in quadrat $\mathrm{B}$, except for the nematode community in the NB soil during the 63 days of the experiments. 
The structure index (SI) and enrichment index (EI) were plotted on different axes to produce a profile to follow nematode community development and, thus, the change in the soil food web. This study follows the food web inference of Ferris et al. (2001). The profile consists of four quadrants representing the food web condition and inference of the soil environment. Resource soil-applied in the microcosm was located in quadrat $\mathrm{C}$, suggesting that the food web consisted of high trophic linkages with a moderate level of natural enhancement, which was reflected in available nutrients (Figure 2). After paddy litter amendment and bacterial enhancement, the nematode community was altered, resulting in food web changes. In soil with bacterial enhancement $(9 \mathrm{~A}, 2 \mathrm{H}$, and $\mathrm{AH})$, the nematode community developed toward a slightly less structured food web with a complex connection provided by omnivores (Qudsianematidae and Thernenematidae) and bacterivores (Cephalobidae, Monhysteridae, and Plectidae) that responded quickly to an enriched environment (Table 2). In contrast, the NB soil nematode community developed into a food web with higher complexity than the resource soil. This community, however, was supported by low numbers of bacterivores necessary for nutrient availability (Figure 2).

The development of the nematode community in the food web profile was consistent with the CCA. The analysis revealed that the community in NB soil differed from other enhanced soil in the microcosm, suggesting the effect of bacteria on the nematode community (Figure 1). The nematode community of NB soil was characterized by a higher number of individuals belonging to omnivorous families Qudsianematidae and Thornenematidae, Cyatolaimidae. Carnivorous Mononchidae was present only in NB soil (Figure 1).

Among the bacterial treatments, 9A enhancement showed more pronounced effects on the nematode community, reflected by their greater abundance and diversity than under the other two treatments $(2 \mathrm{H}$ and $\mathrm{AH})$. The common bacterivores in this soil included Plectidae, Rhabditidae, and Cephlobidae. These three families were also common but less abundant in $2 \mathrm{H}$-and $\mathrm{AH}$ enhancements, except for Rhabditidae, which dominated the microcosm soil system. CCA indicated the nematode community dynamics over 63 days by showing the families present over this period (Figure 1).

\section{Discussion}

Our experiments revealed that the amendment of decomposing paddy litter, as a source of organic matter, in sand growth medium appeared to provide a suitable habitat for soil organisms. The positive effect of soil organic matter on soil biota has often been reported. For example, Scharroba et al. (2016) observed that resource availability and quality influence nematode assemblages, with greater nematode biomass occurring at sites amended with maize shoots than at those amended only with crop plants. The amended soil experiments (NB) demonstrated the ability of nematodes to inhabit the new nutrient-limited environment (Liu et al. 2019). They increased (77, 55\%) in abundance over 41 days (day 21 to day 63), with various families dominating at different times (Table 2, Figure 1). The nematode communities showed similar rates of increase in amended soils with and without bacterial enhancement (1-2 individuals.day ${ }^{-1}$ ). However, based on the number of individual nematodes, the soils with bacterial enhancement showed a greater number of individuals. The paddy litter amendment changed the soil structure and organic $\mathrm{C}$ and $\mathrm{N}$ contents of the microcosm soil. These changes were profound at the temporal scale (Figure 1). The transfer of nematodes and paddy litter amendment to the microcosms during the experiments created disturbances at similar levels across the treated microcosms, which explained the nematode abundance decreased at day 21. Nematodes, however, respond differently to soil modification at the beginning of the experiments, resulting in different abundances over 63 days. These results suggest that at least the nematode community requires between 42 and 63 days to reach similar abundance as that of the resource community. Bacterial addition provides more resources, stimulating more nematode individuals to grow. Consequently, nematodes are more abundant in amended soil with bacterial enhancement than those with no bacteria. The similar rate of increasing abundance across the enhancement treatments in our experiments is most likely due to the available niche provided by the bacteria (De Vries and Caruso 2016; Li et al. 2016; Kardol and Long 2018).

The 9A-bacterial enhancement showed the greatest abundance and diversity of nematode at the family level of the taxon. This is possible because these autotrophic bacteria are less dependent and capable of producing their nutrients (Lladó et al. 2017). Hence, their survival and reproduction might be higher than those of heterotrophic bacteria. The nematode diversity in the 9A enhancement was the greatest. However, this large diversity of family grouping requires confirmation of the high resolution of genus or species grouping. Despite two bacterial isolates (AH) applied to the soil, they appeared to have less influence on nematode abundance. We speculate that this might be due to antagonistic interactions among bacteria, leading to low diversity of the natural bacterial community of the resource soil, thus declining the available niche, but it requires confirmation. These findings suggest use of a single isolate for application.

Bacterial enhancement experiments clearly showed an influence on the nematode community. The treatments significantly supported the nematode community related to the dominant bacterial decomposition pathway after 63 days of treatment, presumably supplying nitrogen to the soil (Figure 2) (Morriien 2016). The bacterial decomposition pathway allows fast turnover of opportunistic bacteria and nematodes, thus rapidly providing soluble nutrients for the soil environment (Kardol and Long 2018; Siebert et al. 2020). This effect differed when bacteria were absent from the amended soil, as demonstrated by NB treatment. In this case, the community was once regulated by the fungal pathway and then dominated by the bacterial pathway. The nematode community changed which larger-body nematodes of omnivores and carnivores were abundant. No bacterial 
addition to soil might increase fungal growth; this is possible because paddy litter contains a large amount of lignin, suitable for fungal degradation but not bacterial degradation (Janusz et al. 2017, Schoenherr et al. 2018). After 41 days, as recorded by the data, fungal decomposition of paddy litter might have provided smaller molecules for use by the natural opportunistic bacteria (De Vries and Caruso 2016). Bacterial growth triggered opportunistic bacterivorous nematodes, but omnivorous nematodes outnumbered their presence and created complex linkages in the food web. It is not clear why the omnivores (Qudsianematidae, c-p: 4) dominated soil with no bacterial treatment. It was perhaps the length of time that allowed these large, long-lived nematodes (Ferris et al. 2001; Andriuzzi and Wall 2018) to grow and reproduce. Such an opportunity is less available in bacterial enhancement treatments than in treatments without enhancement. The additional bacteria stimulate the opportunistic bacterivorous nematode to live and thrive, increasing disturbance to the microcosm soil. Omnivorous and carnivorous nematodes require an undisturbed environment to grow and reproduce (Ferris et al. 2001). Omnivores have been reported to provide stabilizing effects on the food web (Wolkovich 2016). The food web profile revealed a decreasing number of bacterivorous nematodes with time in nutrient-limited soil. This finding suggests the significant importance of the 9A, 2H, and 9A$2 \mathrm{H}$ bacterial enhancements in increasing the soil community, even though litter amendment and natural soil organisms were applied. This approach is especially important when the main goal is to improve soil quality.

In the amended soil with bacterial addition, the nematode community in 9A-enhanced soil was the richest, occupied by various nematodes with the greatest abundance in number (Table 2, Figures 2 and 3). A combination of paddy litter amendment and 9A bacteria most likely facilitated the fastest soil food web development. It shows the highest resemblance of the nematode community and composition to the resource soil. These changes were consistent with $\mathrm{C}$ and $\mathrm{N}$ increases but not the decay rate, which seemed to decline in 9A-bacterial enhanced soil (Scheunemann et al. 2016). The soil C and N indicate the availability of energy sources and nutrients. Thus, an increase in $\mathrm{C}$ and $\mathrm{N}$ in 9A soil might indirectly stimulate nematode growth (Lawrence and Wise 2017; Liu et al. 2019; Liu et al. 2020). Although it was not significantly different, the decomposition rate of paddy litter in 9A soil was notably lower than that in the other two treatments. It might have provided a prolonged substrate for nematodes to live as the organic matter created a suitable microhabitat.

The decomposition rate of paddy litter was significantly no different among the soils with and without bacterial addition. There are two possible explanations proposed. First, paddy litter consists of highly recalcitrant substances containing lignocellulosic biomass consisting of approximately $38 \%$ cellulose, $35 \%$ hemicellulose, and $12 \%$ lignin (Hung et al. 2020) and requires a long time to decompose. The short 63-day experiment does not allow time for the decay rate to possibly differ. Furthermore, the decomposition of resistant substances involves fungal activities; although bacteria collectively are able to degrade lignin (Wilhelm 2019), their entire consortium might not have been present in the microcosm soil, thus prolonging decomposition. Fungi were possibly outnumbered by the bacteria during the microcosm experiments, as indicated by the low fungal decomposition channel (CI). Additionally, the nematode community suggested that the microcosm soil was rich with bacterivorous nematodes. This high abundance of bacterial feeders might indicate bottom-up control (Kardol and Long 2018), supported by bacteria as the available resources (Scharroba et al. 2016; Siebert et al. 2019). It was expected that bacterial enhancement would have assisted the natural bacterial consortium in degrading the paddy litter, thus increasing its decomposition rate. However, that was not the case. The paddy litter decomposition rates were similar among soils with and without bacterial addition.

We conclude that paddy litter amendment in our microcosms improved nutrient-limited soil by providing growth media and microhabitats for soil microorganisms and supported the soil food web conditions represented by the nematode community. Approximately 63 days were required for the nematode community to reach a greater abundance than in the pretreatment conditions. The 9A-, $2 \mathrm{H}-$, and $\mathrm{AH}$ enhancements further improved the soil via their effects in determining the nematode community, its composition, and food web conditions, leading to progression to the dominant bacterial energy channel. The addition of the 9A bacteria to amended soil is suggested to be an efficient way to improve soil function, as shown by the rapid response of the nematode community. When the forest site used as the soil source is taken as the reference to which the ideal soil community and quality are compared, then the community response and development should be an appropriate indicator of soil improvement. Paddy litter decomposition remained relatively unchanged despite the bacterial enhancement of the treated soil and may serve as a better organic matter source due to its slow decomposition and release of nutrients.

As a final point, this research suggests that forest soil, paddy litter amendment, and bacterial $9 \mathrm{~A}$ and $2 \mathrm{H}$ enhancement are methods that can be applied for soil improvement. However, experiments designed to efficiently improve the soil biota community, especially that of nematodes, in the source soil before its use for the amendment of nutrient-limited soil are necessary to reduce dependence on forest soil. Field experiments and soil macronutrients must also be monitored.

\section{ACKNOWLEDGEMENTS}

This research is an undergraduate thesis work supported by a grant from Universitas Jenderal Soedirman to ARM under the scheme of Riset Peningkatan Kompetensi, contract no: 1928/UN23.14/PN/2018. We also thank Meyta Pratiwi for assisting with the bacterial preparation during the study. 


\section{REFERENCES}

Andriuzzi WS, Wall DH. 2018. Grazing and resource availability control soil nematode body size and abundance-mass relationship in semiarid grassland. J Anim Ecol 87: 1407-1417. DOI: 10.1111/13652656.12858.

Beyaert RP, Fox CA. 2008. Assessment of Soil Biological Activity. In: Carter MR, Gregorich EG (eds.) Soil Sampling and Methods of Analysis. CRC Press, Boca Raton.

Bongers T. 1994. Nematode. Koninklijke Nederlandse Natuurhistorische Verenging, Utrecht.

Bongers T. 1999. The Maturity Index, the evolution of nematode lifehistory traits, adaptive radiation and cp-scaling. Plant Soil 212: 13-22 DOI: $10.1023 / \mathrm{A}: 1004571900425$.

De Vries FT, Caruso T. 2016. Eating from the same plate? Revisiting the role of labile carbon inputs in the soil food web. Soil Biol Biochem 102: 4-9. DOI: 10.1016/j.soilbio.2016.06.023.

Fanin N, Kardol P, Farrell M, Kempel A, Ciobanu M, Nilsson M, Gundale MJ, Wardle DA. 2019. Effects of plant functional group removal on structure and function of soil communities across contrasting ecosystems. Ecol Lett 22: 1-9. DOI: 10.1111/ele.13266.

Ferris H, Bongers T, De Goede RGM. 2001. A framework for soil food web diagnostics: Extension of the nematode faunal analysis concept. Appl Soil Ecol 18: 13-29. DOI: 10.1016/S0929-1393(01)00152-4.

Ferris H. 2010. Contribution of nematodes to the structure and function of the soil food web. J Nematol 42: 63-67.

Forge TA, Kimpinski J. 2008. Nematodes. In: Carter MR, Gregorich EG (eds) Soil Sampling and Methods of Analysis. CRC Press, Boca Raton.

Forge TA, Tenuta M. 2008. Indicators of Soil Food Web Properties. In: Carter MR, Gregorich EG (eds) Soil Sampling and Methods of Analysis. CRC Press, Boca Raton.

Hannula SE, Snoek LB, Helmsing NR, Zweers H, Bouffaud M, Bue M, Van Der Putten WH. 2017. Soil networks become more connected and take up more carbon as nature restoration progresses. Nat Commun 8: 14349. DOI: 10.1038/ncomms14349.

Hung TN, Romasanta RR, Hieu NV, Vinh LQ, Du NX, Ngan NVC, Chivenge P, Hung NV. 2020. Rice straw overview: availability, properties, and management practices. In: Gummert M, Hung N, Chivenge P, Douthwaite B (eds) Sustainable Rice Straw Management. Springer International Publishing, New York. DOI: 10.1007/978-3-030-32373-81.

Janusz G, Pawlik A, Sulej J, Swiderska-Burek U, Jarosz-Wilkolazka A, Paszczynski. 2017. Lignin degradation: microorganisms, enzymes involved, genome analysis and evolution. FEMS Microbiol Rev 41: 941-962.

Kardol P, De Long JR. 2018. How anthropogenic shifts in plant community composition alter soil food webs. F1000Res 7: 1-12. DOI: 10.12688/f1000research.13008.1.

Kardol P, Throop HL, Adkins J, De Graaff MA. 2016. A hierarchical framework for studying the role of biodiversity in soil food web processes and ecosystem services. Soil Biol Biochem 102: 33-36. DOI: 10.1016/j.soilbio.2016.05.002.

Lawrence KL, Wise DH. 2017. Long-term resource addition to a detrital food web yields a pattern of responses more complex than pervasive bottom-up control. PeerJ 7 (3572): 1-28. DOI: 10.7717/peerj.3572.

Li N, Pan F, Han XZ, Zhang B. 2016. Development of soil food web of microbes and nematodes under different agricultural practices during the early stage of pedogenesis of a Mollisol. Soil Biol Biochem 98: 208-216. DOI: 10.1016/j.soilbio.2016.04.011.

Liu J, Chen Y, Du C, Liu X, Ma Q, Zhang X, Wang D. 2019. Interactive effects of nitrogen addition and litter on soil nematodes in grassland Eur J Soil Sci 70: 697-706. DOI: 10.1111/ejss.12779.
Liu T, Hu F, Li H. 2019. Spatial ecology of soil nematodes: Perspectives from global to micro scales. Soil Biol Biochem 137: 107565. DOI: 10.1016/j.soilbio.2019.107565.

Liu T, Yang L, Hu Z, Xue J, Lu Y, Chen X, Griffiths BS. 2020. Biochar exerts negative effects on soil fauna across multiple trophic levels in a cultivated acidic soil Biochar exerts negative effects on soil fauna across multiple trophic levels in cultivated acidic soil. Biol Fertil Soils 56: 597-606. DOI: 10.1007/s00374-020-01436-1.

Lladó S, López-mondéjar R, Baldrian P. 2017. Forest soil bacteria: Diversity, involvement in ecosystem processes, and response to global change. Microbiol Mol Biol Rev 81 (2): e00063-16. DOI: 10.1128/MMBR.00063-16.

Maharning AR, Widyastuti A, Pratiwi M. 2016. Soil bacteria and nematode functional diversity: A comparison across vegetation types. In: Setyobudi RH, Nuringtyas TR, Adinurani PG (eds) Towards the sustainable use of biodiversity in a changing environment: from basic to applied research, Proceeding of the $4^{\text {th }}$ International Conference on Biological Science. AIP Conf Proc 1744: 020004. DOI: 10.1063/1.4953478.

Morriien E. 2016. Understanding soil food web dynamics, how close do we get? Soil Biol Biochem 102: 10-13. DOI: 10.1016/j.soilbio.2016.06.022.

Sauvadet M, Chauvat M, Cluzeau D, Maron PA, Villenave C, Bertrand I. 2016. The dynamics of soil micro-food web structure and functions vary according to litter quality. Soil Biol Biochem 95: 262-274. DOI: 10.1016/j.soilbio.2016.01.003.

Scharroba A, Kramer S, Kandeler E, Ruess L. 2016. Spatial and temporal variation of resource allocation in an arable soil drives community structure and biomass of nematodes and their role in the micro-food web. Pedobiologia 59: 111-120. DOI: 10.1016/j.pedobi.2016.03.005.

Scheunemann N, Pausch J, Digel C, Kramer S, Scharroba A, Kuzyakov Y, Kandeler E, Ruess L, Butenschoen O, Scheu S. 2016. Incorporation of root $\mathrm{C}$ and fertilizer $\mathrm{N}$ into the food web of an arable field: Variations with functional group and energy channel. Food Webs 9: 39-45. DOI: 10.1016/j.fooweb.2016.02.006.

Schoenherr S, Ebrahimi M, Czermak P. 2018. Lignin degradation processes and the purification of valuable products. In: Poletto P (eds) Lignin trends and applications. Lignin-Trends Appl. DOI: 10.5772/intechopen.71210.

Siebert J, Ciobanu M, Schädler M, Eisenhauer N. 2020. Climate change and land use induce functional shifts in soil nematode communities. Oecologia 192: 281-294. DOI: 10.1007/s00442-019-04560-4.

Siebert J, Sünnemann M, Auge H, Berger S, Cesarz S, Ciobanu M, Guerrero-Ramirez NR, Eisenhauer, N. 2019. The effects of drought and nutrient addition on soil organisms vary across taxonomic groups, but are constant across seasons. Sci Rep 9: 639. DOI: 10.1038/s41598-018-36777-3.

Van Den Hoogen J, Geisen S, Routh D, Ferris H, Traunspurger W, Wardle DA, Crowther TW. 2019. Soil nematode abundance and functional group composition at a global scale. Nature 527: 194-208. Retrieved from https://www.nature.com/articles/s41586-019-1418-6.

Wilhelm RC. 2019. Bacterial contributions to delignification and lignocellulose degradation in forest soils with metagenomic and quantitative stable isotope probing. ISME J 13 (2): 413-429. DOI: 10.1038/s41396-018-0279-6.

Wilschut RA, Geisen S, Martens H, Kostenko O, de Hollander M, ten Hooven FC, van der Putten WH. 2019. Latitudinal variation in soil nematode communities under climate warming-related rangeexpanding and native plants. Glob Chang Biol 25: 2714-2726. DOI: 10.1111/gcb.14657.

Wolkovich EM. 2016. Reticulated channels in soil food webs. Soil Biol Biochem 102: 18-21. DOI: 10.1016/j.soilbio.2016.06.021.

Zhang Z, Zhang X, Xu M, Zhang S, Huang S, Liang W. 2016. Responses of soil micro-food web to long-term fertilization in a wheat-maize rotation system. Appl Soil Ecol 98: 56-64. DOI: 10.1016/j.apsoil.2015.09.008. 